\title{
High Constitutive Activity Accounts for the Combination of Enhanced Direct Activation and Reduced Potentiation in Mutated $\mathrm{GABA}_{\mathrm{A}}$ Receptors
}

\author{
Allison L. Germann, Daniel J. Shin, Christina R. Kuhrau, Alexander D. Johnson, \\ Alex S. Evers, and Gustav Akk \\ Department of Anesthesiology (A.L.G., D.J.S., C.R.K., A.D.J., A.S.E., G.A.) and Taylor Family Institute for Innovative Psychiatric \\ Research (A.S.E., G.A.), Washington University School of Medicine, St. Louis, Missouri
}

Received December 15, 2017; accepted February 7, 2018

\begin{abstract}
$\mathrm{GABA}_{\mathrm{A}}$ receptors activated by the transmitter GABA are potentiated by several allosterically acting drugs, including the intravenous anesthetic propofol. Propofol can also directly activate the receptor, albeit at higher concentrations. Previous functional studies have identified amino acid residues whose substitution reduces potentiation of GABA-activated receptors by propofol while enhancing the ability of propofol to directly activate the receptor. One interpretation of such observations is that the mutation has specific effects on the sites or processes involved in potentiation or activation. We show here that divergent effects on potentiation and direct activation can be mediated by increased constitutive open probability in the mutant receptor without any specific effect on the interactions between the allosteric drug and the receptor. By simulating
\end{abstract}

$\mathrm{GABA}_{\mathrm{A}}$ receptor activity using the concerted transition model, we demonstrate that the predicted degree of potentiation is reduced as the level of constitutive activity increases. The model further predicts that a potentiating effect of an allosteric modulator is a computable value that depends on the level of constitutive activity, the amplitude of the response to the agonist, and the amplitude of the direct activating response to the modulator. Specific predictions were confirmed by electrophysiological data from the binary $\alpha 1 \beta 3$ and concatemeric ternary $\beta 2 \alpha 1 \gamma 2 \mathrm{~L}+\beta 2 \alpha 1 \mathrm{GABA}_{\mathrm{A}}$ receptors. The corollaries of reduced potentiation due to increased constitutive activity are isobolograms that conform to simple additivity and a loss of separation between the concentration-response relationships for direct activation and potentiation.

\section{Introduction}

The $\mathrm{GABA}_{\mathrm{A}}$ receptor is a member of the Cys-loop superfamily of transmitter-gated ion channels sharing functional and structural features with other members of the family, such as the nicotinic acetylcholine receptor, the glycine receptor, and the 5-hydroxytryptamine type 3 receptor (Bouzat, 2012). The $\mathrm{GABA}_{\mathrm{A}}$ receptor is the major transmitter-gated inhibitory ion channel in the brain and is a target for several clinically important drugs, including the intravenous anesthetic propofol. Wild-type $\mathrm{GABA}_{\mathrm{A}}$ receptors activated by the transmitter GABA are potently and efficaciously potentiated

This work was supported by the National Institutes of Health National Institute of General Medical Sciences [Grants R01-GM108580 and R01GM108799], the Center for the Investigation of Membrane Excitability Diseases at Washington University [Grant CIMED-17-03], and the Taylor Family Institute for Innovative Psychiatric Research.

https://doi.org/10.1124/mol.117.111435. by propofol. Propofol can also directly activate the receptor in the absence of GABA; however, the concentration-response relationship for direct activation is shifted to higher propofol concentrations compared with that for potentiation of GABAactivated receptors (Hales and Lambert, 1991; Ruesch et al., 2012).

Propofol acts allosterically i.e., by interacting with sites distinct from the orthosteric transmitter binding site (Yip et al., 2013; Jayakar et al., 2014). Functional studies have identified regions where amino acid substitutions modify the actions of propofol (Thompson et al., 1999; Carlson et al., 2000; Krasowski et al., 2001; Richardson et al., 2007; Eaton et al., 2015). Interestingly, in some cases, the mutations differentially modify the potentiating and activating effects of propofol. For example, receptors containing the $\beta 2(\mathrm{G} 219 \mathrm{~F})$ mutation are directly activated by propofol but show little enhancement of GABA-elicited currents by propofol or

ABBREVIATIONS: $C_{\mathrm{GABA}}$, a measure of gating efficacy in the presence of GABA; $C_{\mathrm{PRO}}$, a measure of gating efficacy in the presence of propofol; $\mathrm{EC}_{5 \%}$, a response with peak amplitude of $5 \%$ of the response to saturating $\mathrm{GABA} ; \mathrm{K}_{\mathrm{GABA}}$, equilibrium dissociation constant of the closed receptor to GABA; $K_{P R O}$, equilibrium dissociation constant of the closed receptor to propofol; $P_{o, \text { const }}$, open probability of constitutively active

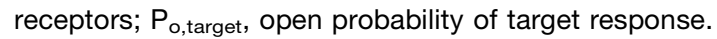


another allosteric modulator pentobarbital (Carlson et al., 2000). Similarly, introduction of the L9'S mutation in the TM2 domain of the $\beta 2$ subunit generates receptors that are highly sensitive to GABA or propofol separately but show little enhancement of the current response when GABA is combined with the allosteric agent (Thompson et al., 1999).

Disparate effects of a mutation on potentiation and direct activation have served as a basis to hypothesize that distinct sites or structural requirements underlie the potentiating and activating actions of a drug (Carlson et al., 2000). This, however, appears incompatible with the coagonist concerted transition model that dictates that the same sites mediate both actions and has been successfully used to describe wildtype $\mathrm{GABA}_{\mathrm{A}}$ receptor activation and modulation by propofol (Ruesch et al., 2012; Shin et al., 2018).

A common feature of the mutated $\mathrm{GABA}_{\mathrm{A}}$ receptors showing opposing effects on potentiation and activation is a high level of constitutive activity i.e., channel activity in the absence of any GABAergic agonists. It is well understood that increased constitutive activity correlates with lower $\mathrm{EC}_{50}$ for direct activation. The relationship between the two can be expressed through the state function in the concerted transition model for receptor activation (Monod et al., 1965; Karlin, 1967; Forman, 2012), which is in good agreement with the experimentally established relationship between $\mathrm{EC}_{50}$ and constitutive activity (Chang and Weiss, 1999; Akk et al., 2018). To test whether a high level of constitutive activity can account for reduced potentiation of the $\mathrm{GABA}_{\mathrm{A}}$ receptor by allosteric agents, we conducted a series of simulations of current responses using the concerted transition model. The simulations indicate that increased constitutive activity correlates with reduced potentiation. The model-based predictions were verified by experimental data from binary and ternary $\mathrm{GABA}_{\mathrm{A}}$ receptors.

\section{Materials and Methods}

Receptor Expression. Wild-type and mutant $\mathrm{GABA}_{\mathrm{A}}$ receptors were expressed in Xenopus oocytes. Harvesting of oocytes was conducted under the Guide for the Care and Use of Laboratory Animals as adopted and promulgated by the National Institutes of Health. The animal protocol was approved by the Animal Studies Committee of Washington University in St. Louis.

The receptors were expressed as binary receptors consisting of human $\alpha 1$ and $\beta 3$ subunits or as concatemeric ternary receptors consisting of $\beta 2-\alpha 1-\gamma 2 \mathrm{~L}$ and $\beta 2-\alpha 1$ constructs of rat origin. The generation and properties of concatemeric receptors were described previously (Bracamontes and Steinbach, 2009; Bracamontes et al., 2011; Akk et al., 2018). The mutations [ $\beta 3(\mathrm{Y} 143 \mathrm{~W})$ and $\alpha 1(\mathrm{~L} 263 \mathrm{~S})$ ] were made using the QuikChange site-directed mutagenesis kit (Agilent Technologies, Santa Clara, CA). The coding region was fully sequenced prior to use. The cDNAs subcloned in the pcDNA3 vector were linearized with XbaI (NEB Laboratories, Ipswich, MA), and the cRNAs generated using mMessage mMachine (Ambion, Austin, TX). The oocytes were injected with a total of $10-12 \mathrm{ng}$ cRNA (in a 5:1 ratio for $\alpha 1 / \beta 3$ subunits or a 1:1 ratio for concatemeric constructs) and incubated in ND96 solution with supplements (96 $\mathrm{mM} \mathrm{NaCl}, 2 \mathrm{mM}$ $\mathrm{KCl}, 1.8 \mathrm{mM} \mathrm{CaCl}_{2}, 1 \mathrm{mM} \mathrm{MgCl}_{2}, 2.5 \mathrm{mM}$ Na pyruvate, $5 \mathrm{mM} \mathrm{HEPES}$, $100 \mathrm{U} / \mathrm{ml}$ plus $100 \mu \mathrm{g} / \mathrm{ml}$ penicillin and streptomycin, and $50 \mu \mathrm{g} / \mathrm{ml}$ gentamycin, $\mathrm{pH} 7.4$ ) at $16^{\circ} \mathrm{C}$ for $1-3$ days before electrophysiological recordings were conducted.

Electrophysiology. Electrophysiological recordings were conducted using the standard two-electrode voltage clamp technique. The oocytes were clamped at $-60 \mathrm{mV}$. The chamber (RC-1Z; Warner Instruments, Hamden, CT) was perfused continuously at 5-8 ml per minute with ND96. Solutions were gravity applied from 30-ml glass syringes with glass Luer slips via Teflon tubing to reduce adsorption and were switched manually. A typical experiment consisted of recording of a 10-second baseline, then a 20- to 60 -second drug application, followed by bath (ND96) application until full recovery. The current responses were amplified with an Axoclamp 900A (Molecular Devices, Sunnyvale, CA) or OC-725C amplifier (Warner Instruments), digitized with a Digidata 1320 or 1200 series digitizer (Molecular Devices), and stored using pClamp (Molecular Devices). The current traces were analyzed using Clampfit (Molecular Devices) to determine peak amplitude.

Data Analysis. In experiments involving responses to single concentrations of agonists and combinations of agonists, the effect of a potentiator is expressed as the potentiation response ratio, calculated as the peak response to GABA plus potentiator (propofol or pentobarbital) divided by the peak response to GABA alone. The findings are expressed as the mean \pm S.D. (number of cells).

Modulation by propofol was also examined by measuring the effect of coapplication of a low concentration of propofol on the GABA concentration-response relationship. The concentration-response curves were fitted to eq. 1 :

$$
\mathrm{Y}=\mathrm{Y}_{\min }+\left(\mathrm{Y}_{\max }-\mathrm{Y}_{\min }\right) \times \frac{[\mathrm{GABA}]^{\mathrm{n}_{\mathrm{H}}}}{[\mathrm{GABA}]^{\mathrm{n}_{\mathrm{H}}}+\mathrm{EC}_{50}^{\mathrm{n}_{\mathrm{H}}}}
$$

where $\mathrm{EC}_{50}$ is the concentration of GABA producing a half-maximal effect, $\mathrm{n}_{\mathrm{H}}$ is the Hill slope, and $\mathrm{Y}_{\min }$ and $\mathrm{Y}_{\max }$ are the low- and highconcentration asymptotes, respectively. The fitting parameters were determined individually for each cell. The results are given as the mean \pm S.D. (number of cells).

Simulations of Current Responses. To simulate current responses, we employed the state function of the receptor (eq. 2) (Chang and Weiss, 1999; Ruesch et al., 2012):

$$
\mathrm{P}_{\mathrm{o}}=\frac{1}{1+\mathrm{L} \times\left[\frac{1+[\text { agonist }] / K}{1+[\text { agonist }] / c K}\right]^{N}}
$$

where $\mathrm{P}_{\mathrm{o}}$ is the open probability of the receptor (or, for a population of receptors, the fraction of receptors in the active states), $K$ is the equilibrium dissociation constant of the closed receptor for the agonist (GABA or propofol), $N$ corresponds to the number of binding sites, and the parameter $c$ is a measure of gating efficacy that can be expressed as the ratio of the open receptor equilibrium dissociation constant to the closed receptor equilibrium dissociation constant. $L$ is the equilibrium gating constant of the unliganded receptor and is related to the probability that an unliganded receptor is constitutively active $\left(\mathrm{P}_{\mathrm{o} \text {, const }}\right)$ through $\mathrm{L}=\left(1-\mathrm{P}_{\mathrm{o}, \text { const }}\right) / \mathrm{P}_{\mathrm{o} \text {, const }}$.

To simulate responses to GABA or propofol individually, the values of $K_{\mathrm{GABA}}, c_{\mathrm{GABA}}$ (affinity and efficacy measures in the presence of GABA), and $K_{\mathrm{PRO}}$ and $c_{\mathrm{PRO}}$ (affinity and efficacy measures in the presence of propofol) for the $\alpha 1 \beta 3, \alpha 1 \beta 3$ (Y143W), and $\beta 2 \alpha 1 \gamma 2 \mathrm{~L}+\beta 2 \alpha 1$ receptors taken from previous reports (Eaton et al., 2016; Akk et al., 2018; Shin et al., 2018) were used in eq. 2 . For the $\alpha 1 \beta 3$ wild-type receptor, $K_{\mathrm{GABA}}$ was $1.6 \mu \mathrm{M}, c_{\mathrm{GABA}}$ was $0.02, K_{\mathrm{PRO}}$ was $4.7 \mu \mathrm{M}$, and $c_{\mathrm{PRO}}$ was 0.24 . For $\alpha 1 \beta 3(\mathrm{Y} 143 \mathrm{~W}), K_{\mathrm{GABA}}$ was $2.8 \mu \mathrm{M}, c_{\mathrm{GABA}}$ was $0.02, K_{\mathrm{PRO}}$ was $23 \mu \mathrm{M}$, and $c_{\mathrm{PRO}}$ was 0.27 . For the $\beta 2 \alpha 1 \gamma 2 \mathrm{~L}+\beta 2 \alpha 1$ receptor, $K_{\mathrm{GABA}}$ was $72 \mu \mathrm{M}$, $c_{\mathrm{GABA}}$ was $0.0033, K_{\mathrm{PRO}}$ was $21 \mu \mathrm{M}$, and $c_{\mathrm{PRO}}$ was 0.22 .

To simulate a response to the combination of GABA plus propofol, eq. 2 was modified to incorporate gating by propofol as background activity (eq. 3):

$$
\mathrm{P}_{\mathrm{o}}=\frac{1}{1+\mathrm{L}^{*} \times\left[\frac{1+[\mathrm{GABA}] / K_{\mathrm{GABA}}}{1+[\mathrm{GABA}] / c_{\mathrm{GABA}} K_{\mathrm{GABA}}}\right]^{N_{\mathrm{GABA}}}}
$$

In this equation, $\mathrm{L}^{*}$ is a modified equilibrium gating constant reflecting background activity in the presence of propofol that can be formally expressed as shown in eq. 4 : 


$$
\mathrm{L}^{*}=\mathrm{L} \times\left[\frac{1+[\text { propofol }] / K_{\mathrm{PRO}}}{1+[\text { propofol }] / c_{\mathrm{PRO}} K_{\mathrm{PRO}}}\right]^{N_{\mathrm{PRO}}}
$$

In practice, $L^{*}$ was calculated from receptor open probability in the presence of propofol as shown in eq. 5:

$$
\mathrm{L}^{*}=\left(1-\mathrm{P}_{\mathrm{o}, \mathrm{PRO}}\right) / \mathrm{P}_{\mathrm{o}, \mathrm{PRO}}
$$

To express current responses as fractional values, the concentrationresponse relationships simulated in units of open probability were normalized using eq. 6 :

$$
\text { Fractional response }=\frac{\mathrm{P}_{\mathrm{o}}-\mathrm{P}_{\mathrm{o}, \text { const }}}{\mathrm{P}_{\mathrm{o}, \max }-\mathrm{P}_{\mathrm{o}, \text { const }}}
$$

where $P_{o}, P_{o, \text { const }}$, and $P_{o, \max }$ reflect open probability at a given agonist concentration, open probability of constitutively active receptors, and maximal open probability in the presence of the given agonist, respectively.

To predict the potentiation response ratios, we first simulated the GABA and propofol concentration-response curves using eqs. 2 and 6 . The experimental fractional response to propofol was converted to units of open probability (Shin et al., 2018), from which $L^{*}$ was calculated using eq. 5 . The response to the combination of GABA plus propofol was subsequently estimated as activation by GABA at modified $\mathrm{L}^{*}$, using eq. 3 . The response to the combination of GABA plus propofol could also be modeled by calculating the response to propofol in the presence of background activity elicited by GABA. Both approaches yielded identical results (data not shown). The response to the combination of GABA plus pentobarbital was modeled by determining the response to GABA in the presence of background activity due to pentobarbital.

The nominal concentrations of GABA and propofol used in the specific experiments were adjusted to generate responses with peak amplitudes equal to the experimental values. In other words, the calculations utilizing experimental data reflect responses to combinations of GABA and propofol at actual, experimental EC values rather than to combinations of specific concentrations of GABA and propofol. This was done to negate any influence of day-to-day experimental variability.

\section{Results}

Propofol Is a Weak Potentiator of the $\alpha 1 \beta 3(Y 143 W)$ Receptor. Propofol allosterically activates $\mathrm{GABA}_{\mathrm{A}}$ receptors and potentiates GABA-elicited currents (Hales and Lambert, 1991; Ruesch et al., 2012). In oocytes expressing the wild-type $\alpha 1 \beta 3$ receptor, the application of $1 \mu \mathrm{M}$ propofol elicited a current response with the mean peak amplitude that was approximately $0.4 \%$ of the peak response to saturating GABA. Coapplication of $1 \mu \mathrm{M}$ propofol with $0.3 \mu \mathrm{M}$ GABA $\left(\mathrm{EC}_{5}\right)$ potentiated the current response by a mean $4.2 \pm 1.6$-fold (ratio of peak responses to GABA plus propofol/GABA; $n=$ 6 cells).

The $\alpha 1 \beta 3$ receptors containing the Y143W mutation in the $\beta 3$ subunit are potently and efficaciously activated by GABA and propofol (Eaton et al., 2016). However, potentiation of GABA-elicited currents by propofol is reduced. In the $\alpha 1 \beta 3(\mathrm{Y} 143 \mathrm{~W})$ receptor, the application of $0.1 \mu \mathrm{M}$ propofol, which by itself generated a response with a mean peak amplitude of $1.7 \%$ of the response to saturating GABA, potentiated the peak response to $0.02 \mu \mathrm{M}$ GABA $\left(\mathrm{EC}_{9}\right)$ by $1.3 \pm 0.2$-fold $(n=8$ cells $)$. Sample current responses are shown in Fig. 1A. The data are summarized in Fig. 1B.

Reduced Potentiation Is Accounted for by Increased Constitutive Activity in Mutant Receptors. A previous study noted increased constitutive activity in oocytes expressing the $\alpha 1 \beta 3(\mathrm{Y} 143 \mathrm{~W})$ receptor (Eaton et al., 2016). The picrotoxin-sensitive outward current in the mutant receptor was $6 \% \pm 1 \%$ of the response to saturating GABA, whereas no consistent changes in holding current during the application of picrotoxin were observed in oocytes expressing the wildtype $\alpha 1 \beta 3$ receptor (Fig. $1 \mathrm{~A}$ ).
A

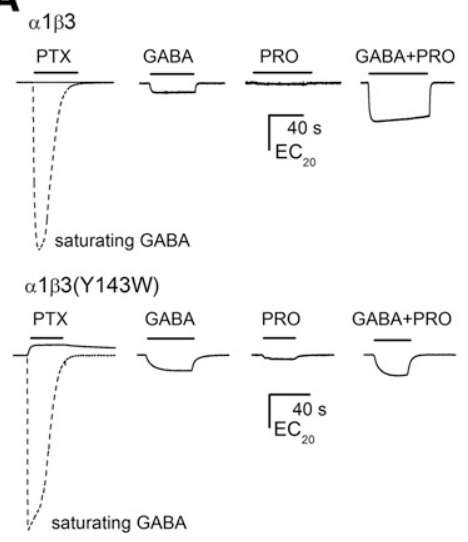

B

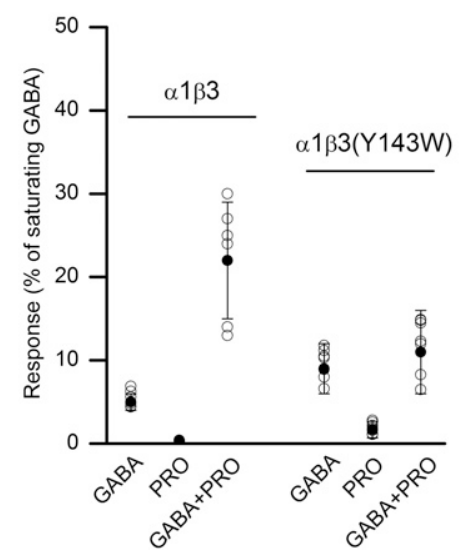

C

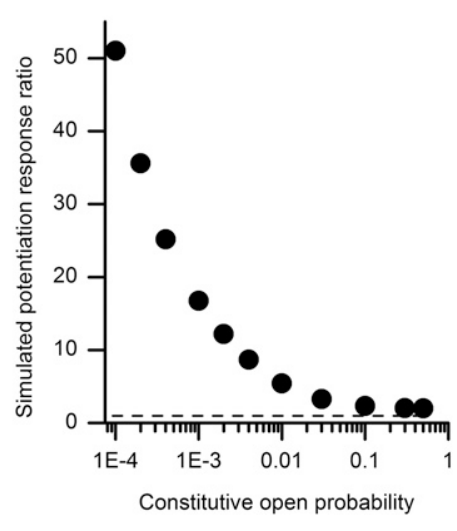

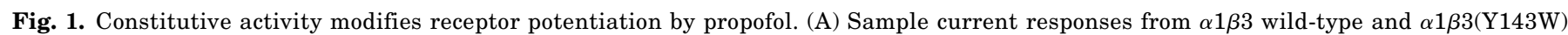

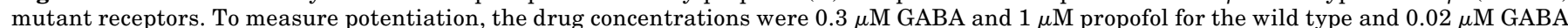

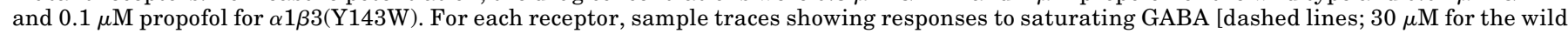

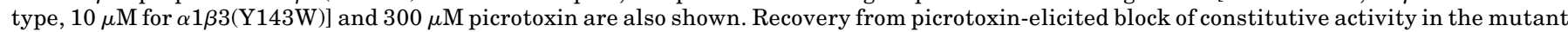

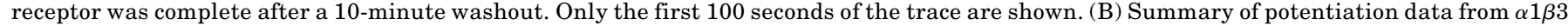

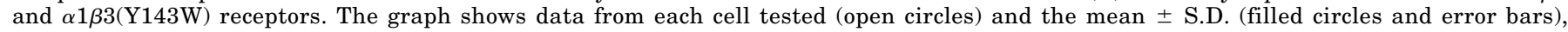

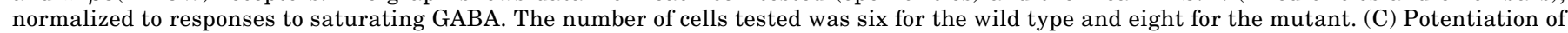

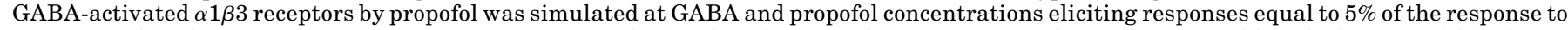

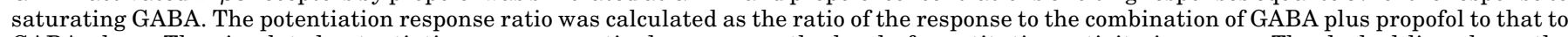

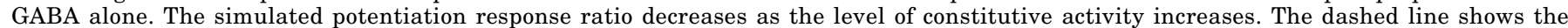
response to GABA alone (1). PRO, propofol; PTX, picrotoxin. 
To test whether the difference in constitutive activity can account for differences observed in potentiation by propofol, we simulated current responses using the concerted transition model (Chang and Weiss, 1999; Forman, 2012) and the affinity and efficacy estimates previously reported for $\alpha 1 \beta 3$ and $\alpha 1 \beta 3(\mathrm{Y} 143 \mathrm{~W})$ receptors (Eaton et al., 2016). In these simulations, the presence of propofol is assumed to increase background activity (i.e., reduce L), which underlies the increase in the response to GABA (see the Materials and Methods for details). In the wild-type receptor, the application of propofol produced a response with the mean peak amplitude of $0.4 \%$ of the response to saturating GABA. After a conversion of the relative response to the units of open probability (eq. 6), we calculate (eq. 5) that exposure to propofol is expected to generate a background activity corresponding to an $\mathrm{L}^{*}$ of 262. Comparison of the predicted responses to GABA at an L of 1000 in the absence of propofol (eq. 2), and at an $\mathrm{L}^{*}$ of 262 (eq. 3) yields a potentiation ratio of 3.5. The experimental potentiation ratio was $4.2 \pm 1.6$ (see above).

In the $\alpha 1 \beta 3(\mathrm{Y} 143 \mathrm{~W})$ receptor, the application of propofol $\left(\mathrm{EC}_{1.7 \%}\right)$ resulted in background activity corresponding to an $\mathrm{L}^{*}$ of 12 . From the predicted responses to GABA at $\mathrm{L}$ of 15.7 (control condition) and at an $\mathrm{L}^{*}$ of 12 (in the presence of propofol), we obtain a simulated potentiation response ratio of 1.4. For comparison, the experimentally determined potentiation ratio was $1.3 \pm 0.2$.

The $\beta 3(\mathrm{Y} 143 \mathrm{~W})$ mutation has been shown to affect the activation properties of the $\alpha 1 \beta 3$ receptor in the presence of propofol (Eaton et al., 2016), and it may be argued that this contributes to reduced potentiation in $\alpha 1 \beta 3(\mathrm{Y} 143 \mathrm{~W})$. To address this possibility, we turned to the $\alpha 1$ (L263S) $\beta 3$ receptor. The $\alpha 1$ (L263S) mutation has been shown to increase constitutive activity and to shift the activation concentrationresponse relationship to lower agonist concentrations in the $\alpha 1 \beta 2 \gamma 2$ ternary configuration (Chang et al., 1996; Chang and Weiss, 1999), but the mutation does not affect receptor affinity to propofol (Shin et al., 2018). Incorporation of the $\alpha 1$ (L263S) mutation drastically increased constitutive activity in the $\alpha 1 \beta 3$ receptor $\left(\mathrm{P}_{\mathrm{o}, \mathrm{const}}=0.54 \pm 0.11 ; n=7\right)$. To test the effect of the mutation on potentiation, we coapplied $0.1 \mu \mathrm{M}$ propofol, a concentration that elicited a response with a mean peak amplitude of $3 \%$ of the response to saturating GABA, with $0.001 \mu \mathrm{M}$ GABA $\left(\mathrm{EC}_{5}\right)$. The combination of GABA plus propofol elicited a response with a mean peak amplitude that was $1.5 \pm 0.5$-fold ( $n=5$ ) greater than the response to GABA alone. The predicted response ratio, simulated using eqs. 3 and 5, was 1.6. We infer that increased constitutive activity in the mutant receptors leads to reduced apparent potentiation in a quantitatively predictable manner.

Relationship between Constitutive Activity and Potentiation. To gain a more general view of the relationship between constitutive activity and apparent potentiation, we modeled responses to GABA and the combination of GABA plus propofol at different levels of constitutive activity. For convenience, we used the affinity $\left(K_{\mathrm{C}}\right)$ and efficacy $(c)$ values for GABA and propofol estimated for the $\alpha 1 \beta 3$ wild-type receptor (Eaton et al., 2016), and we changed the value of the gating equilibrium constant of unliganded receptors (L).

We began by calculating the concentrations of GABA and propofol that when applied alone elicit a response with a peak amplitude of $5 \%$ of the response to saturating GABA (dubbed $\mathrm{EC}_{5 \%}$ ) at different values of $\mathrm{L}$. The concerted transition model predicts that as constitutive activity increases ( $\mathrm{L}$ decreases), the concentration of agonist needed to produce an $\mathrm{EC}_{5 \%}$ response decreases. We then simulated the response to the combination of the two agonists at each pair of concentrations. The results indicate that as constitutive activity increases, the simulated potentiation response ratio (predicted peak response in the presence of GABA plus propofol/predicted peak response in the presence of GABA) decreases (Fig. 1C). Under conditions in which half of the receptors are constitutively active $\left(\mathrm{P}_{\mathrm{o} \text {,const }}=0.5\right)$, combining $\mathrm{GABA}$ and propofol at concentrations that each separately produce a response that is $5 \%$ of the response to saturating GABA is predicted to result in approximately doubling of the response to GABA alone i.e., an arithmetic sum of the responses to either agonist individually.

A

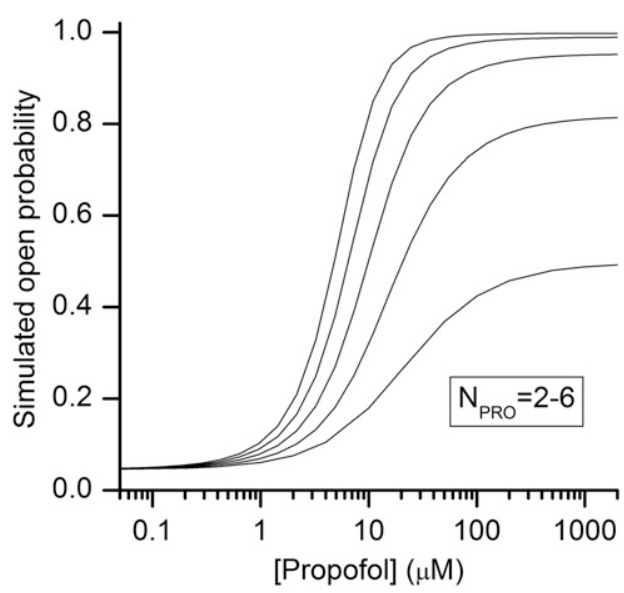

B

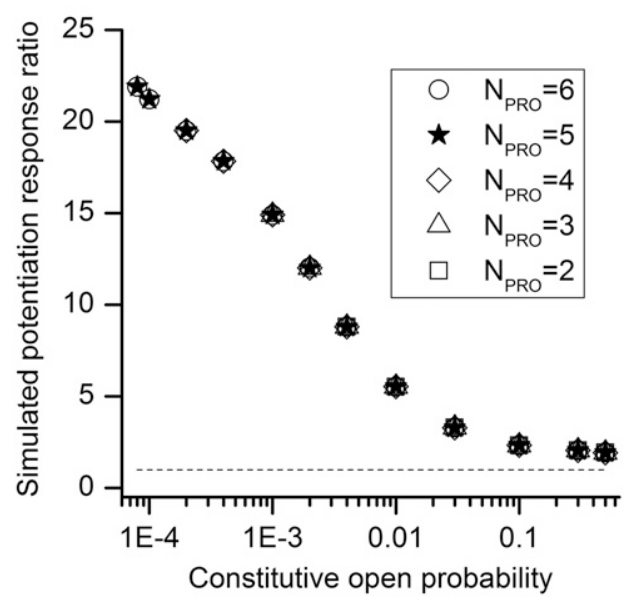

Fig. 2. The simulated relationship between the properties of a potentiator and the extent of potentiation. (A) Simulated concentration-response curves for potentiation of $\mathrm{EC}_{5}$ GABA-activated wild-type $\beta 2 \alpha 1 \gamma 2 \mathrm{~L}+\beta 2 \alpha 1$ receptors by propofol. The $K_{\mathrm{PRO}}$ was $21 \mu \mathrm{M}$ and $c_{\mathrm{PRO}}$ was 0.22 (Shin et al., 2018). To mimic potentiation by different modulators, the number of propofol binding sites was varied from two to six (bottom to top). (B) Simulated potentiation response ratios for receptors activated by $\mathrm{EC}_{5}$ GABA and potentiated by propofol at a concentration that, when applied alone, elicits a response with the same peak current $\left(\mathrm{EC}_{5 \%}\right)$, at different $\mathrm{P}_{\mathrm{o} \text {,const }}$. The simulations show that the potentiation response ratio is identical for all imposed values of

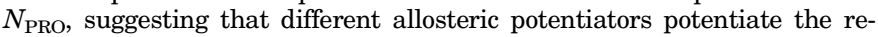
ceptor by the same degree as long as the direct activating response to the potentiator is constant. The dashed line shows the response to GABA alone (1). $\mathrm{N}_{\text {PRO }}$, number of propofol binding sites. 
The Relationship between Constitutive Activity, Direct Activation, and the Potentiation Ratio. The experiments and simulations above examined potentiation of GABA-elicited currents by the anesthetic propofol in the binary $\alpha 1 \beta 3 \mathrm{GABA}_{\mathrm{A}}$ receptor. We next turned to the ternary receptor formed of concatemeric $\beta 2 \alpha 1 \gamma 2 \mathrm{~L}$ and $\beta 2 \alpha 1$ constructs. To determine how the intrinsic properties of the modulating drug affect potentiation, we first simulated current responses to GABA in the absence and presence of propofol, using the affinity and efficacy values reported previously for this receptor (Shin et al., 2018). The properties of the modulator were then altered by changing the nominal number of binding sites for the drug on the receptor. This is a simple and convenient way to modify the energetic contribution $(\Delta \mathrm{G})$ made by the modulating drug that links the number of binding sites $(N)$ and gating efficacy $(c)$ through $\Delta \mathrm{G}=$ $N_{\text {modulator }} \mathrm{RT} \times \ln \left(c_{\text {modulator }}\right)$.

Figure 2A shows that as the number of propofol binding sites $\left(N_{\mathrm{PRO}}\right)$ is reduced from 6 to 2 , the simulated potentiation curves are shifted to higher propofol concentrations and saturate at lower amplitudes. These changes reflect the effect of reduced energetic contribution at lower $N_{\text {PRO }}$. We next evaluated the effect of altering the number of propofol binding sites on the potentiation response ratio. Figure $2 \mathrm{~B}$ shows the simulated potentiation response ratio as a function of constitutive open probability at $N_{\text {PRO }}$ constrained to $2-6$. The calculations were done for the concatemeric ternary receptor activated by $\mathrm{EC}_{5} \mathrm{GABA}$ in the absence and presence of $\mathrm{EC}_{5 \%}$ propofol. The major finding is that the potentiation response ratios are predicted to be identical for all nominal $N_{\text {PRO }}$ values. In other words, in the concerted transition model, coapplication of a modulator at $\mathrm{EC}_{5 \%}$ increases the response to $\mathrm{EC}_{5}$ GABA by a factor that solely depends on the constitutive open probability of the receptor.

These simulations suggest that the extent of potentiation in a given receptor is identical for all combinations of agonists and modulators as long as the concentrations of the individual drugs are selected to generate a fixed, predetermined response when applied individually. To test this experimentally, we compared potentiation of concatemeric ternary receptors by propofol and pentobarbital. Both are allosteric GABAergic agents but differ in their abilities to activate and modulate the $\mathrm{GABA}_{\mathrm{A}}$ receptor (Steinbach and Akk, 2001; Ruesch et al., 2012; Nourmahnad et al., 2016; Ziemba and Forman, 2016).

The experiments were conducted on wild-type concatemeric receptors $\left(\mathrm{P}_{\mathrm{o} \text {,const }}=0.0001\right.$; Akk et al., 2018) and on receptors containing the gain-of-function $\alpha 1$ (L263S) mutation in a single $\alpha 1$ subunit ( $\mathrm{P}_{\mathrm{o} \text {,const }}=0.014$; Akk et al., 2018) or in both $\alpha 1$ subunits $\left(\mathrm{P}_{\mathrm{o} \text {,const }}=0.10\right.$; Shin et al., 2018). The concentrations of GABA, propofol, and pentobarbital were selected to produce small (approximately $\mathrm{EC}_{5-15}$ ) responses when applied individually. The experimental potentiation response ratios in the wild-type receptor were $9.3 \pm 3.4\left(n=6\right.$ cells; GABA: $\mathrm{EC}_{10}$; propofol: $\left.\mathrm{EC}_{6 \%}\right)$ and $9.7 \pm 1.7\left(n=6\right.$ cells; GABA: $\mathrm{EC}_{9}$; pentobarbital: $\mathrm{EC}_{6 \%}$ ) for propofol and pentobarbital, respectively. For comparison, the predicted potentiation ratios calculated for the experimental EC values were 10.8 for propofol and 12.2 for pentobarbital. In the $\beta 2 \alpha 1 \gamma 2 \mathrm{~L}+$ $\beta 2 \alpha 1(\mathrm{~L} 263 \mathrm{~S})$ receptor, the potentiation response ratios were $2.9 \pm 0.6\left(n=9\right.$ cells; GABA: $\mathrm{EC}_{12}$; propofol: $\left.\mathrm{EC}_{6 \%}\right)$ and $4.3 \pm$ $1.2\left(n=6\right.$ cells; GABA: $\mathrm{EC}_{13}$; pentobarbital: $\left.\mathrm{EC}_{8 \%}\right)$ in the presence of propofol and pentobarbital, respectively. The predicted potentiation ratios at experimental EC values were 3.7 and 4.1 for propofol and pentobarbital, respectively. In the $\beta 2 \alpha 1$ (L263S) $\gamma 2 \mathrm{~L}+\beta 2 \alpha 1$ (L263S) receptor, the experimental potentiation response ratios were $2.1 \pm 0.2(n=5$ cells; GABA: $\mathrm{EC}_{11}$; propofol: $\left.\mathrm{EC}_{7 \%}\right)$ and $2.1 \pm 0.4\left(n=6\right.$ cells; GABA: $\mathrm{EC}_{13}$; pentobarbital: $\mathrm{EC}_{6 \%}$ ) for propofol and pentobarbital, respectively. The predicted potentiation response ratios were 2.1 for propofol and 1.9 for pentobarbital. We infer that the degree of potentiation depends on the level of unliganded activity and that it is further determined by the ability of the modulator to directly activate the receptor. Sample currents are shown in Fig. 3, A-C. The data are summarized in Fig. 3D.

The Effect of Constitutive Activity on Isoboles of Additivity. Energetic additivity between the effects of orthosteric and allosteric agonists underlies the curvilinear isoboles and apparent synergy when GABA and propofol are coapplied (Shin et al., 2017). To determine the effect of constitutive activity on apparent synergy, we modeled current responses from the $\alpha 1 \beta 3$ receptor to combinations of GABA and propofol at different levels of constitutive activity. The data are presented as isobolograms with the target response having an open probability $\left(\mathrm{P}_{\mathrm{o} \text {,target }}\right)$ of 0.5 (Fig. 4). We used receptor open probability in these simulations rather than a relative current response because open probability has an absolute rather than relative value and is therefore more directly interpretable in the context of various cellular or behavioral endpoints.

The data indicate that the predicted deviation from the linear isobole of additivity decreases as constitutive activity increases (Fig. 4). If we assign "1/2[GABA]" as one-half of the concentration of GABA needed to generate a response with a $\mathrm{P}_{\mathrm{o} \text {,target }}$ of 0.5 , then the degree of synergy can be expressed through the concentration of propofol needed to potentiate the response to $1 / 2[\mathrm{GABA}]$ to a $\mathrm{P}_{\mathrm{o}}$ of 0.5 . If the drug effects are strictly additive, this concentration ([propofol $]_{\text {linear }}$ ) should be equal to $50 \%$ of the concentration of propofol that when applied alone generates a response with a $\mathrm{P}_{\mathrm{o}}$ of 0.5 . In Figure 5, we plotted the ratio between [propofol] $]_{\text {linear }}$ and the concentration of propofol predicted by the concerted transition model to produce a response with a $\mathrm{P}_{\mathrm{o}}$ of 0.5 in the presence of $1 / 2[\mathrm{GABA}]$ ([propofol $]_{\mathrm{CTM}}$ ). The results indicate that this ratio decreases as constitutive activity increases. In other words, the concentrations of propofol predicted by the concerted transition model and the linear isobole needed to produce $\mathrm{P}_{\mathrm{o}}$ of 0.5 in the presence of $1 / 2$ [GABA] become more similar as constitutive activity increases. The simulations also indicate that the ratio between [propofol] $]_{\text {linear }}$ and [propofol] $]_{\mathrm{CTM}}$ at a given level of $\mathrm{P}_{\mathrm{o} \text {,const }}$ becomes smaller as the target $P_{o}$ is reduced (Fig. 5).

Constitutive Activity Affects the Difference in $\mathbf{E C}_{50} \mathrm{~s}$ for Direct Activation and Potentiation. The $\mathrm{EC}_{50}$ for direct activation is greater than the $\mathrm{EC}_{50}$ for potentiation. This concept applies to both propofol potentiation of receptors activated by a low, fixed concentration of GABA and GABA potentiation of receptors activated by a low concentration of propofol. The shift in the $\mathrm{EC}_{50} \mathrm{~s}$ is due to the extra free energy provided by the secondary drug that acts by increasing background activity (Forman, 2012; Shin et al., 2018). Here, we have modeled the effect of constitutive activity on the $\mathrm{EC}_{50} \mathrm{~s}$ for direct activation and potentiation. For simplicity and convenience, we again used the activation parameters estimated for the wild-type $\alpha 1 \beta 3 \mathrm{GABA}_{\mathrm{A}}$ receptor (Eaton 
A

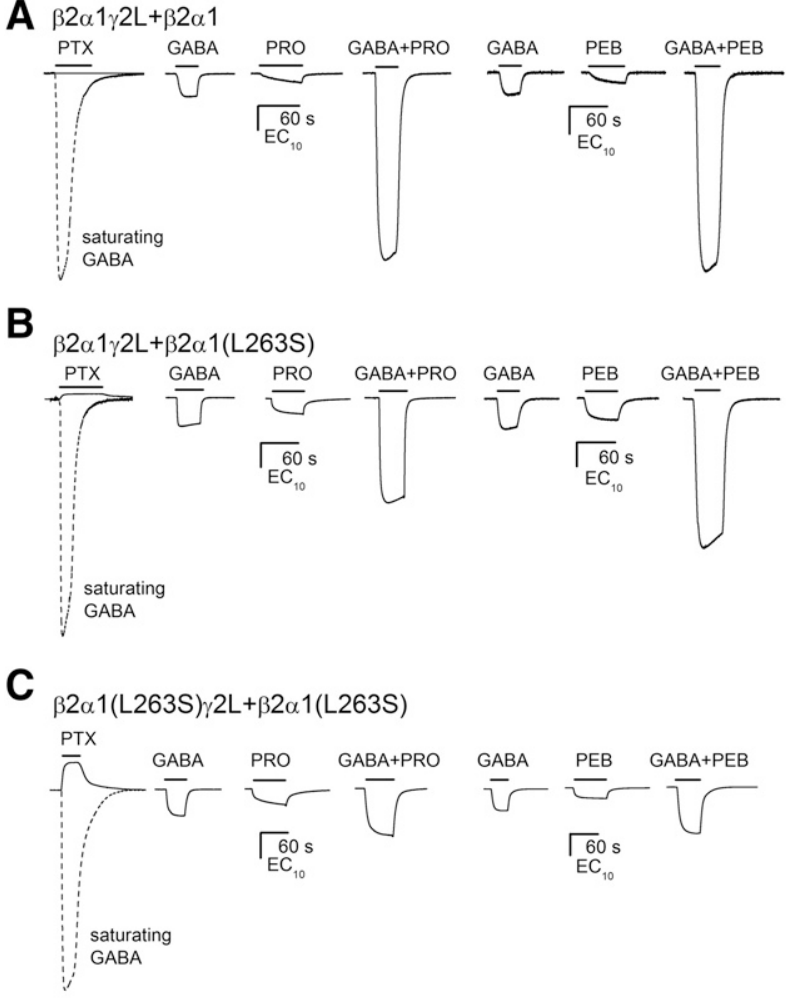

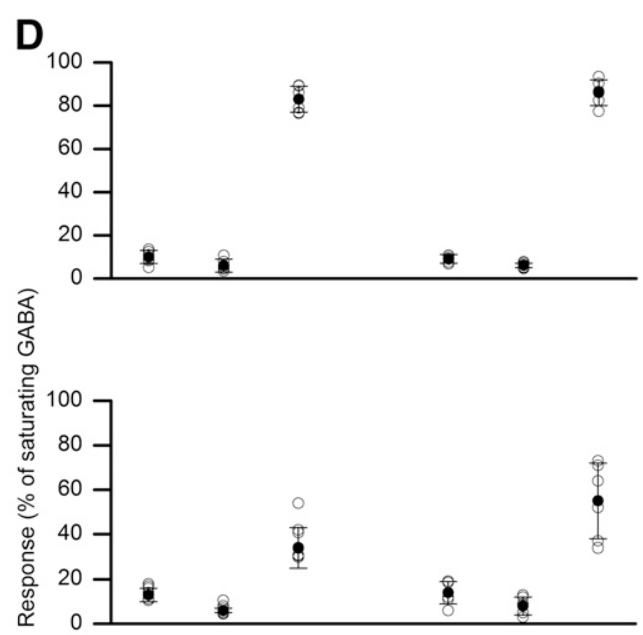

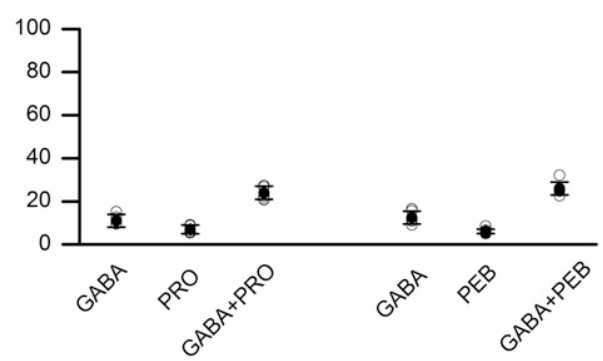

Fig. 3. The relationship between constitutive activity, direct activation, and the extent of potentiation. (A) Sample current traces from the wild-type $\beta 2 \alpha 1 \gamma 2 \mathrm{~L}+\beta 2 \alpha 1$ receptor. The receptors were exposed to $\mathrm{GABA}\left(\mathrm{EC}_{9-10}\right)$, propofol $\left(\mathrm{EC}_{6}\right)$, or pentobarbital ( $\left.\mathrm{EC}_{6}\right)$ and the combination of GABA plus propofol or GABA plus pentobarbital. (B) Sample current traces from the $\beta 2 \alpha 1 \gamma 2 \mathrm{~L}+\beta 2 \alpha 1(\mathrm{~L} 263 \mathrm{~S})$ receptor. The receptors were exposed to GABA (EC G $_{12}$ ) , propofol $\left(\mathrm{EC}_{6}\right)$, or pentobarbital $\left(\mathrm{EC}_{8.5}\right)$ and the combination of GABA plus propofol or GABA plus pentobarbital. (C) Sample current traces from the $\beta 2 \alpha 1$ (L263S) $\gamma$ $2 \mathrm{~L}+\beta 2 \alpha 1$ (L263S) receptor. The receptors were exposed to GABA $\left(\mathrm{EC}_{11-13}\right)$, propofol $\left(\mathrm{EC}_{7}\right)$, or pentobarbital $\left(\mathrm{EC}_{6}\right)$ and the combination of GABA plus propofol or GABA plus pentobarbital. (A-C) Responses to $300 \mu \mathrm{M}$ picrotoxin and saturating GABA (the dashed trace) from a same cell are shown to demonstrate differences in constitutive activity in the wild-type and mutant receptors. The mean $\mathrm{P}_{\mathrm{o} \text {,const }}$ is 0.0001 in the wild-type receptor (Akk et al., 2018), 0.014 in $\beta 2 \alpha 1 \gamma 2 \mathrm{~L}+\beta 2 \alpha 1$ (L263S) (Akk et al., 2018), and 0.1 in $\beta 2 \alpha 1$ (L263S) $\gamma 2 \mathrm{~L}+\beta 2 \alpha 1$ (L263S) (Shin et al., 2018). (D) Summary of potentiation data from $\beta 2 \alpha 1 \gamma 2 \mathrm{~L}+\beta 2 \alpha 1, \beta 2 \alpha 1 \gamma 2 \mathrm{~L}+\beta 2 \alpha 1$ (L263S), and $\beta 2 \alpha 1$ (L263S) $\gamma 2 \mathrm{~L}+\beta 2 \alpha 1$ (L263S) receptors. The graph shows data from each cell tested (open circles) and the mean \pm S.D. (filled circles and error bars), normalized to responses to saturating GABA. The number of cells tested was six for the wild type tested with propofol or pentobarbital. In $\beta 2 \alpha 1 \gamma 2 \mathrm{~L}+\beta 2 \alpha 1$ (L263S), the number of cells was six for propofol and pentobarbital. In $\beta 2 \alpha 1$ (L263S) $\gamma 2 \mathrm{~L}+\beta 2 \alpha 1(\mathrm{~L} 263 \mathrm{~S})$, the number of cells was five for propofol and six for pentobarbital. The findings indicate that 1) apparent potentiation is greater in the receptor with less constitutive activity (wild-type) and 2) the extent of potentiation is similar for propofol and pentobarbital. PEB, pentobarbital; PRO, propofol; PTX, picrotoxin.

et al., 2016). We simulated the activation and potentiation data for propofol in the absence and presence of low GABA and for GABA in the absence and presence of low propofol. We confirmed the concept and predictions by comparing the $\mathrm{EC}_{50} \mathrm{~S}$ for GABA in the absence and presence of low propofol in two receptors [ $(\alpha 1 \beta 3$ and $\alpha 1 \beta 3(\mathrm{Y} 143 \mathrm{~W})]$ differing in their level of constitutive activity.

The data summarized in Fig. $6 \mathrm{~A}$ show that for any level of constitutive activity, the $\mathrm{EC}_{50}$ for direct activation by propofol is greater than the $\mathrm{EC}_{50}$ for propofol potentiation of currents elicited by $\mathrm{EC}_{5}$ GABA. However, the difference between the $\mathrm{EC}_{50} \mathrm{~S}$ decreases as the constitutive open probability increases. Figure $6 \mathrm{~B}$ shows the simulated GABA $\mathrm{EC}_{50} \mathrm{~s}$ in the absence and presence of propofol that when applied alone produce a response of $5 \%$ of the response to saturating GABA. Again, the $\mathrm{EC}_{50}$ for direct activation is greater than the $\mathrm{EC}_{50}$ for potentiation. However, the difference is predicted to be smaller at high $\mathrm{P}_{\mathrm{o} \text {,const }}$.

To confirm this prediction experimentally, we compared GABA concentration-response relationships in the absence and presence of a low concentration of propofol in $\alpha 1 \beta 3$ and $\alpha 1 \beta 3\left(\mathrm{Y} 143 \mathrm{~W}\right.$ ) receptors (Fig. $6 \mathrm{C}$ ). The $\mathrm{EC}_{50}$ for GABA was $1.4 \mu \mathrm{M}$ in the wild-type receptor (estimated $\mathrm{P}_{\mathrm{o}, \text { const }}=0.001$ ) (Eaton et al., 2016). Coapplication of $4 \mu \mathrm{M}$ propofol, which generated a response with a $\mathrm{P}_{\mathrm{o}}$ of $0.09 \pm 0.03$ when applied alone, shifted the $\mathrm{EC}_{50}$ for GABA to $0.19 \pm 0.06 \mu \mathrm{M}\left(\mathrm{pEC}_{50}=\right.$ $6.75 \pm 0.15 ; n=5$ ). The predicted $\mathrm{EC}_{50}$ for the wild-type receptor activated by GABA in the presence of propofol was $0.09 \mu \mathrm{M}$. In the $\alpha 1 \beta 3(\mathrm{Y} 143 \mathrm{~W})$ mutant $\left(\mathrm{P}_{\mathrm{o}, \text { const }}=0.06\right)$, the GABA $\mathrm{EC}_{50}$ was $0.18 \mu \mathrm{M}$ in the absence of other GABAergic drugs (Eaton et al., 2016). In the presence of $0.5 \mu \mathrm{M}$ propofol $\left(\mathrm{EC}_{8}\right.$, corresponds to $\mathrm{P}_{\mathrm{o}}$ of 0.15$)$, the $\mathrm{EC}_{50}$ for GABA was $0.15 \pm$ $0.14 \mu \mathrm{M}\left(\mathrm{pEC}_{50}=6.97 \pm 0.39 ; n=12\right)$. The simulated $\mathrm{EC}_{50}$ for GABA in the presence of propofol was $0.11 \mu \mathrm{M}$.

The prediction that propofol $\mathrm{EC}_{50}$ s for direct activation and potentiation of GABA-elicited currents are more similar at high $\mathrm{P}_{\mathrm{o} \text {,const }}$ i.e., the prediction described in Fig. $6 \mathrm{~A}$ was serendipitously confirmed in our recent study (Shin et al., 2018). Specifically, we showed that in the $\beta 2 \alpha 1 \gamma 2 \mathrm{~L}+\beta 2 \alpha 1$ receptor $\left(\mathrm{P}_{\mathrm{o} \text {,const }}=0.0001\right)$, the propofol $\mathrm{EC}_{50}$ s were $73 \mu \mathrm{M}$ for direct activation and $2.9 \mu \mathrm{M}$ for potentiation of currents elicited by $10 \mu \mathrm{M}$ GABA $\left(\mathrm{EC}_{17}\right)$. In receptors containing the 

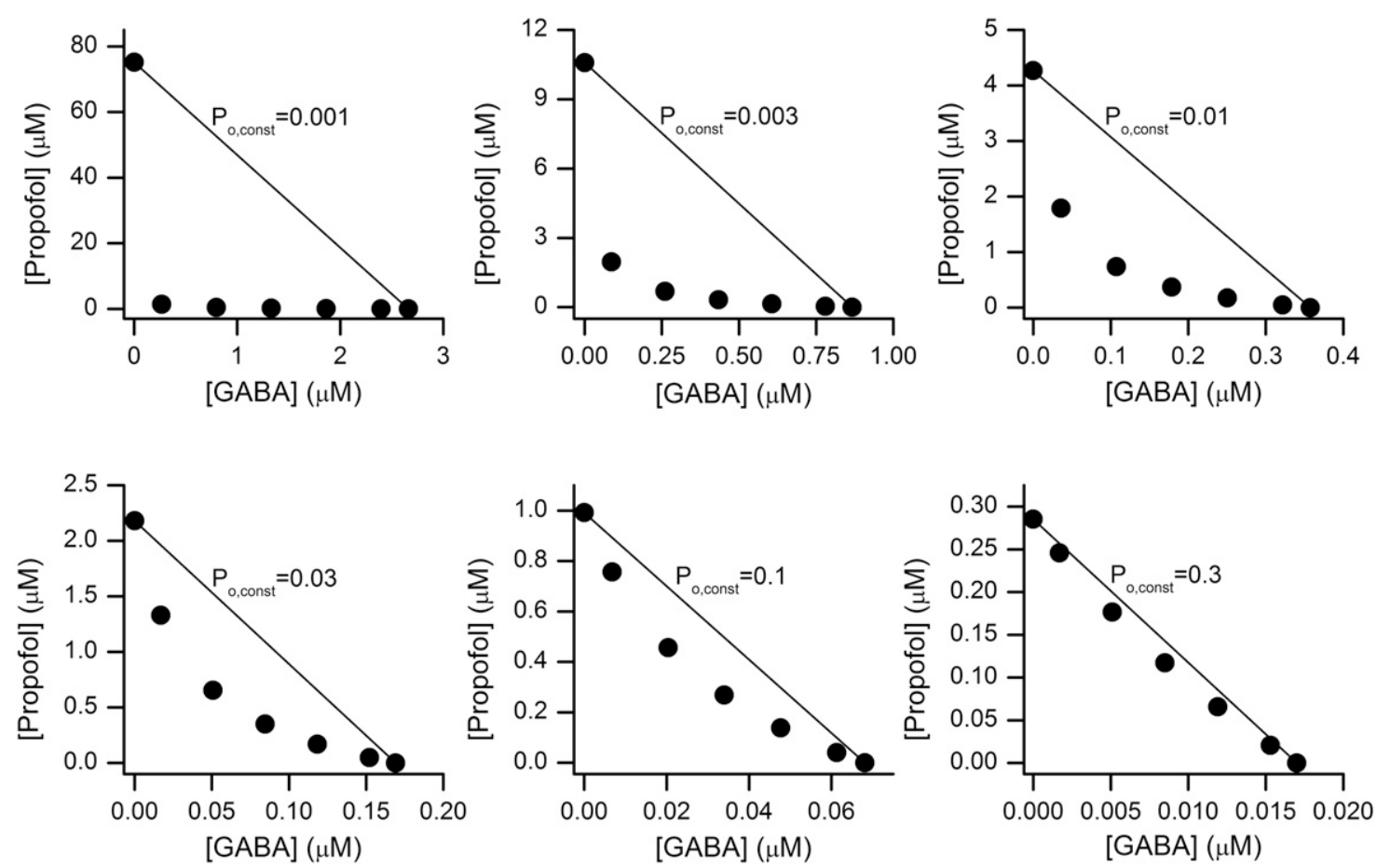

Fig. 4. Constitutive activity modifies the predicted isoboles of additivity. The figure shows simulated isobolograms for activation of the $\alpha 1 \beta 3$ receptor by GABA, propofol, and combinations of GABA plus propofol with the target open probability of 0.5 at different levels of constitutive activity. The straight line in each panel represents the linear isobole traditionally associated with additive effects of the two drugs. The data points show the simulated isoboles based on energetic additivity using the affinity and efficacy data published previously (Eaton et al., 2016). The $K_{\mathrm{GABA}}$ was $1.6 \mu \mathrm{M}, c_{\mathrm{GABA}}$ was $0.02, K_{\mathrm{PRO}}$ was $4.7 \mu \mathrm{M}$, and $c_{\mathrm{PRO}}$ was 0.24 . The numbers of binding sites were constrained to two and five for GABA and propofol, respectively. The data indicate that as $\mathrm{P}_{\mathrm{o} \text {,const }}$ increases, the predicted isoboles approach linearity.

$\alpha 1(\mathrm{~L} 263 \mathrm{~S})$ mutation in both constructs $\left(\mathrm{P}_{\mathrm{o}, \text { const }}=0.1\right)$, the propofol $\mathrm{EC}_{50}$ was $3.0 \mu \mathrm{M}$ for direct activation and $1.1 \mu \mathrm{M}$ for potentiation of receptors activated by $0.1 \mu \mathrm{M}$ GABA $\left(\mathrm{EC}_{22}\right)$. The experimental $\mathrm{EC}_{50}$ ratios, $25 \pm 4$ for the wild type and $2.7 \pm 0.3$ for the mutant, are in general agreement with the predicted calculated $\mathrm{EC}_{50}$ ratios of 29 and 1.8 for the wild-type and mutant receptors, respectively.

\section{Discussion}

We have investigated potentiation of the $\mathrm{GABA}_{\mathrm{A}}$ receptor in the framework of the concerted transition model. The model makes the following specific predictions: 1) the potentiation ratio, expressed as the ratio of the peak amplitude in the presence of agonist plus potentiator to the peak amplitude in the presence of agonist alone, decreases as the level of constitutive activity increases; 2) the apparent potentiating effects of different modulating drugs are equal and predictable and depend only on the level of constitutive activity as long as the drugs are applied at concentrations that elicit a constant direct activating effect; and 3) reduced potentiation due to increased constitutive activity is associated with isobolograms that conform to simple additivity and with more similar concentration-response relationships for potentiation and direct activation. The predictions were verified by experimental data from binary and ternary $\mathrm{GABA}_{\mathrm{A}}$ receptors.

Potentiating drugs are often characterized by their ability to enhance current responses to the transmitter, GABA. The concentration of GABA in such experiments is selected to produce a low, subsaturating response, usually between $5 \%$ and $20 \%$ of the response to saturating GABA $\left(\mathrm{EC}_{5-20}\right)$.
A change in the potentiation response ratio (e.g., after introduction of a mutation) is typically considered to result from modifications to the interactions between the modulator and the receptor (effect on affinity) or from changes in the transduction mechanism (effect on gating). We show here that a change in constitutive open probability i.e., the ability of the $\mathrm{GABA}_{\mathrm{A}}$ receptor to gate in the absence of any GABAergic drugs modifies the potentiation response ratio and accounts for observed reduction in potentiation of receptors containing the $\beta(\mathrm{Y} 143 \mathrm{~W})$ or $\alpha(\mathrm{L} 263 \mathrm{~S})$ mutations. The simulations, confirmed by experimental data, indicate that at $\mathrm{P}_{\mathrm{o} \text {,const }}>0.1$, the response to the combination of GABA plus potentiator approaches the sum of the individual responses to the transmitter and the potentiating drug (Figs. $1 \mathrm{C}$ and $2 \mathrm{~B}$ ). Increased constitutive activity is associated with increases in apparent affinity and efficacy of direct activation (Chang and Weiss, 1999; Forman, 2012; Ehlert, 2014a; Akk et al., 2018). Therefore, receptors with high $\mathrm{P}_{\mathrm{o} \text {,const }}$ exhibit efficient direct activation but weak potentiation.

Selective reduction or loss of potentiation by allosteric drugs in receptors showing increased spontaneous activity has been observed previously. Incorporation of the L259S mutation in TM2 of the $\beta 2$ subunit produced receptors that exhibited large leak current and direct activation by pentobarbital and propofol. However, potentiation of $\mathrm{EC}_{20}$ GABA currents by these allosteric agents was drastically reduced compared with that in the wild type (Thompson et al., 1999). Stewart et al. (2008) showed that introduction of the $\alpha 1$ (M236W) mutation increases constitutive activity in the $\alpha 1 \beta 2 \gamma 2 \mathrm{~L}$ receptor. The anesthetic etomidate efficaciously activated the mutant receptors but was a weak potentiator of GABA-activated 


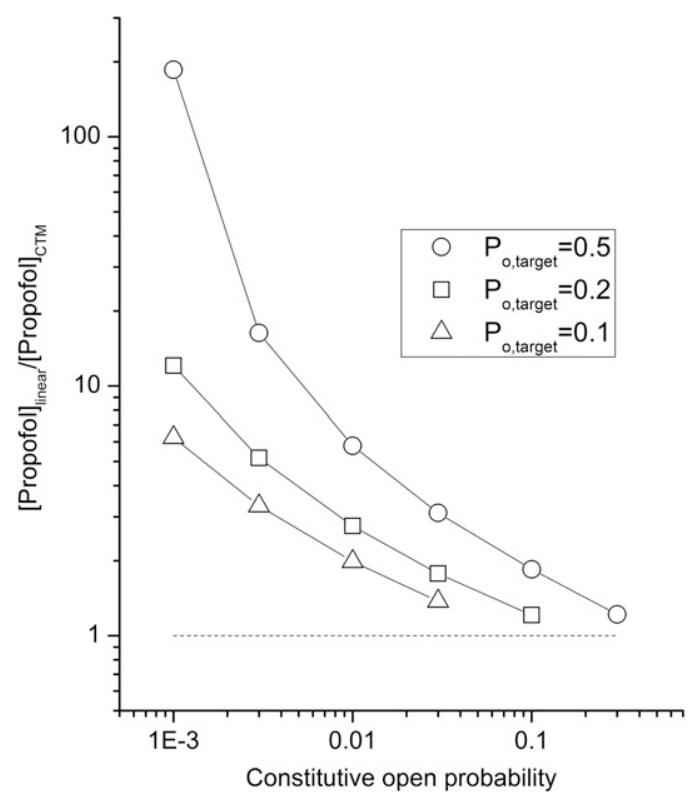

Fig. 5. Constitutive activity is predicted to affect apparent synergy. Constitutive open probability affects the simulated ratio of [propofol] $]_{\text {linear }}$ over [propofol] $]_{\mathrm{CTM}}$, defined as the displacement between the linear isobole of additivity and the isobole predicted by the concerted transition model. A ratio greater than unity (shown with a dashed line) indicates that energetic additivity predicts a synergistic interaction between GABA and propofol. The simulations indicate that the apparent degree of synergy decreases as the difference between the target $\left(\mathrm{P}_{\mathrm{o} \text {,target }}\right)$ and basal open probabilities $\left(\mathrm{P}_{\mathrm{o}, \text { const }}\right)$ decreases.

receptors. $\mathrm{GABA}_{\mathrm{A}}$ receptors containing the $\varepsilon$ subunit are directly activated by pentobarbital and propofol but show little potentiation of GABA-elicited currents (Davies et al., 1997). Given that $\alpha \beta \varepsilon$ receptors are constitutively active $\left(\mathrm{P}_{\mathrm{o}, \mathrm{ponst}}>\right.$ 0.2; Neelands et al., 1999; Thompson et al., 2002), we propose that the apparent resistance to the modulatory actions of anesthetics in these receptors is a consequence of high $\mathrm{P}_{\mathrm{o} \text {,const }}$ and not because of impaired binding of the anesthetic drugs.

Our simulations, confirmed by experimental data, indicate that the extent of potentiation does not depend on the intrinsic properties of a potentiating drug as long as the potentiator is applied at a concentration that produces a fixed direct activating effect. In other words, the concerted transition model predicts that all allosteric potentiating drugs modulate the response to transmitter by an identical factor, provided the drugs are applied at concentrations that (when applied alone) elicit a direct activating effect of the same magnitude. We have confirmed this prediction experimentally by comparing potentiation of wild-type and mutated receptors by propofol and pentobarbital (Fig. 3). Furthermore, for a wide range of $\mathrm{P}_{\mathrm{o} \text {,const }}$, the potentiation response ratios are not sensitive to the ability of GABA to activate the receptor per se, provided the potentiator is tested at the same fractional GABA response (i.e., constant $\mathrm{EC}$ value). Thus, the potentiation response ratio has a predictable and identical value for various agonist-modulator combinations, as long as the orthosteric agonist and the allosteric potentiator each elicit a fixed-amplitude response. However, the potentiation response ratio depends on $\mathrm{P}_{\mathrm{o} \text {,const, }}$ which is an intrinsic property of the receptor.

These findings may appear unintuitive but are easily understood in the framework of the concerted transition model. In this model (Monod et al., 1965; Forman, 2012;
A

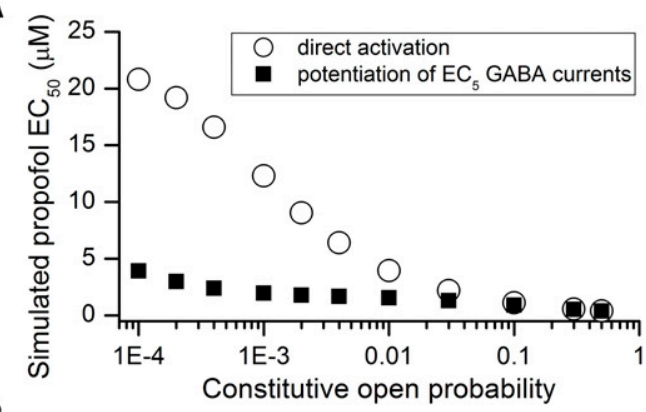

B

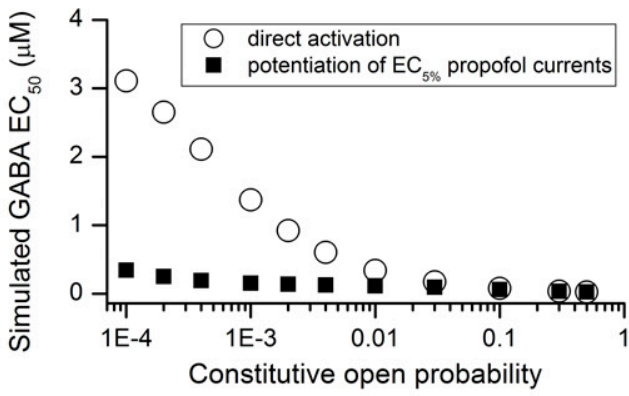

C

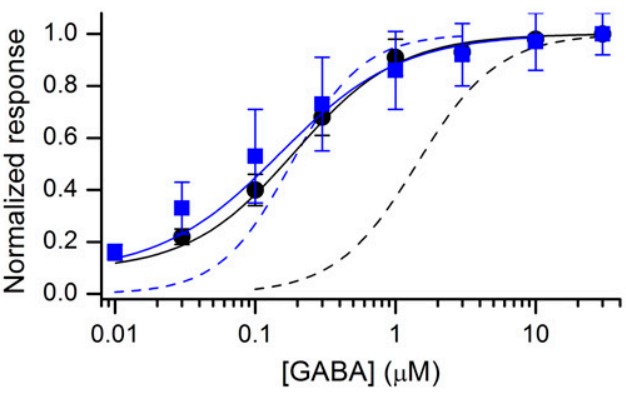

Fig. 6. Constitutive activity affects the positions of the concentrationresponse relationships for direct activation and potentiation. (A) Simulated propofol $\mathrm{EC}_{50}$ values for direct activation and potentiation of receptors activated by $\mathrm{EC}_{5}$ GABA at different levels of constitutive activity. The simulations were done using the affinity and efficacy values determined previously for the wild-type $\alpha 1 \beta 3$ receptor (Eaton et al., 2016). The $K_{\mathrm{GABA}}$ was $1.6 \mu \mathrm{M}, c_{\mathrm{GABA}}$ was $0.02, K_{\mathrm{PRO}}$ was $4.7 \mu \mathrm{M}$, and $c_{\mathrm{PRO}}$ was 0.24 . The numbers of binding sites were constrained to two and five for GABA and propofol, respectively. (B) Simulated EC $_{50}$ values for activation by GABA in the absence and presence of propofol at concentrations that elicited a response that was 5\% of the response to saturating GABA at the given $\mathrm{P}_{\mathrm{o} \text {,const. }}$ (C) Concentration-response curves for GABA in the absence and presence of $4 \mu \mathrm{M}$ (wild-type) or $0.5 \mu \mathrm{M}$ propofol $[\alpha 1 \beta 3(\mathrm{Y} 143 \mathrm{~W})]$. The data points (black circles: wild type; blue squares: mutant) show the mean \pm S.D. from 5 to 12 cells. The solid-line curves show simulations using the following averaged fitting parameters: wild-type, GABA plus propofol (black line): $\mathrm{Y}_{\min }=0.09, \mathrm{EC}_{50}=0.19 \mu \mathrm{M}, \mathrm{n}_{\mathrm{H}}=1.16$; and $\alpha 1 \beta 3(\mathrm{Y} 143 \mathrm{~W})$, GABA plus propofol (blue line): $\mathrm{Y}_{\min }=0.08, \mathrm{EC}_{50}=0.15 \mu \mathrm{M}, \mathrm{n}_{\mathrm{H}}=1.01$. The dashed black (wild-type) and blue (mutant) lines show the concentrationresponse data for GABA alone with $\mathrm{EC}_{50} \mathrm{~s}$ of $1.4 \mu \mathrm{M}$ for the wild type and $0.18 \mu \mathrm{M}$ for the mutant from a prior study (Eaton et al., 2016).

Ehlert, 2014b), the binding of the transmitter leads to stabilization of the open state, whereas the application of the allosteric potentiator can be viewed as reducing the free energy difference to be overcome by the transmitter. Therefore, as long as the energetic contribution is similar, the nature of the allosteric drug is of little matter, as we recently showed for the shift in GABA $\mathrm{EC}_{50}$ produced by various allosteric agents (Akk et al., 2018). Conversely, the transmitter can be considered to increase background activity and reduce the free energy difference to be overcome by the allosteric drug (Shin et al., 2018). 
Isobolographic analysis can be used to characterize drug interactions (Loewe, 1953; Tallarida, 2006). We previously showed that the combination of GABA plus propofol exhibits apparent synergy as the data representing activity for the drug combination fall outside the linear isobole of additivity (Shin et al., 2017). We now show that the predicted isoboles become more linear (i.e., less synergistic) as constitutive activity increases. Less apparent synergy is also observed when the target effect is reduced and the difference between $\mathrm{P}_{\mathrm{o} \text {,const }}$ and $\mathrm{P}_{\mathrm{o} \text {,target }}$ becomes smaller. These findings make an interesting prediction. It is predicted that drug combinations show more apparent synergy for endpoints requiring a higher target $\mathrm{P}_{\mathrm{o}}$ such as loss of righting, whereas endpoints associated with a smaller potentiating effect on the $\mathrm{GABA}_{\mathrm{A}}$ receptor (e.g., anxiolysis) are expected to follow linear isoboles of additivity. Likewise, receptors that are constitutively active (e.g., $\varepsilon$ subunit-containing receptors) are predicted to mediate effects showing less apparent synergy in the presence of combinations of agonists. We also note that in constitutively active receptors, direct activation, rather than potentiation of transmitter-gated activity, is the major contributor of the actions of GABAergic anesthetics.

In summary, we have shown that constitutive activity can affect the extent of potentiation and that in receptors with $\mathrm{P}_{\mathrm{o} \text {,const }}>0.1$, currents elicited by an orthosteric agonist are minimally potentiated by allosteric potentiators even when the receptor is directly activated by the allosteric drug. We also showed that the potentiating effects of allosteric modulators are identical, provided the modulators are applied at concentrations that elicit the same direct activating effect. The downstream corollaries of increased constitutive activity and reduced potentiation are more similar direct activation and potentiation curves for the allosteric drugs and drug interactions that conform to additivity rather than synergy.

\section{Acknowledgments}

The authors thank Dr. Joe Henry Steinbach for valuable suggestions.

\section{Authorship Contributions}

Participated in research design: Evers, Akk.

Conducted experiments: Germann, Shin, Kuhrau, Johnson.

Performed data analysis: Germann, Shin, Kuhrau, Johnson, Akk. Wrote or contributed to the writing of the manuscript: Germann, Shin, Kuhrau, Johnson, Evers, Akk.

\section{References}

Akk G, Shin DJ, Germann AL, and Steinbach JH (2018) GABA type A receptor activation in the allosteric coagonist model framework: relationship between $\mathrm{EC}_{50}$ and basal activity. Mol Pharmacol 93:90-100.

Bouzat C (2012) New insights into the structural bases of activation of Cys-loop receptors. J Physiol Paris 106:23-33.

Bracamontes J, McCollum M, Esch C, Li P, Ann J, Steinbach JH, and Akk G (2011) Occupation of either site for the neurosteroid allopregnanolone potentiates the opening of the $\mathrm{GABA}_{\mathrm{A}}$ receptor induced from either transmitter binding site. $\mathrm{Mol}$ Pharmacol 80:79-86.

Bracamontes JR and Steinbach JH (2009) Steroid interaction with a single potentiating site is sufficient to modulate GABA-A receptor function. Mol Pharmacol $\mathbf{7 5}$ 973-981.

Carlson BX, Engblom AC, Kristiansen U, Schousboe A, and Olsen RW (2000) A single glycine residue at the entrance to the first membrane-spanning domain of the $\gamma$-aminobutyric acid type A receptor $\beta(2)$ subunit affects allosteric sensitivity to GABA and anesthetics. Mol Pharmacol 57:474-484.
Chang Y, Wang R, Barot S, and Weiss DS (1996) Stoichiometry of a recombinant GABA $_{A}$ receptor. J Neurosci 16:5415-5424.

Chang Y and Weiss DS (1999) Allosteric activation mechanism of the $\alpha 1 \beta 2 \gamma 2$ $\gamma$-aminobutyric acid type A receptor revealed by mutation of the conserved M2 leucine. Biophys $J$ 77:2542-2551.

Davies PA, Hanna MC, Hales TG, and Kirkness EF (1997) Insensitivity to anaesthetic agents conferred by a class of $\left.\operatorname{GABA}_{\mathrm{A}}\right)$ receptor subunit. Nature $\mathbf{3 8 5}$ : $820-823$.

Eaton MM, Cao LQ, Chen Z, Franks NP, Evers AS, and Akk G (2015) Mutational analysis of the putative high-affinity propofol binding site in human $\beta 3$ homomeric GABA $_{\mathrm{A}}$ receptors. Mol Pharmacol 88:736-745.

Eaton MM, Germann AL, Arora R, Cao LQ, Gao X, Shin DJ, Wu A, Chiara DC, Cohen JB, Steinbach JH, et al. (2016) Multiple non-equivalent interfaces mediate direct activation of $\mathrm{GABA}_{\mathrm{A}}$ receptors by propofol. Curr Neuropharmacol 14:772-780.

Ehlert FJ (2014a) Affinity and efficacy of orthosteric ligands at ligand-gated ion channels, in Affinity and Efficacy, pp 73-160, World Scientific Publishing Co. Pte. Ltd., Singapore, Singapore.

Ehlert FJ (2014b) Analysis of allosteric interactions at ligand-gated ion channels, in Affinity and Efficacy, pp 179-249, World Scientific Publishing Co. Pte. Ltd., Singapore, Singapore.

Forman SA (2012) Monod-Wyman-Changeux allosteric mechanisms of action and the pharmacology of etomidate. Curr Opin Anaesthesiol 25:411-418.

Hales TG and Lambert JJ (1991) The actions of propofol on inhibitory amino acid receptors of bovine adrenomedullary chromaffin cells and rodent central neurones. Br J Pharmacol 104:619-628.

Jayakar SS, Zhou X, Chiara DC, Dostalova Z, Savechenkov PY, Bruzik KS, Dailey WP, Miller KW, Eckenhoff RG, and Cohen JB (2014) Multiple propofol-binding sites in a $\gamma$-aminobutyric acid type A receptor $\left(\mathrm{GABA}_{\mathrm{A}} \mathrm{R}\right)$ identified using a photoreactive propofol analog. J Biol Chem 289:27456-27468.

Karlin A (1967) On the application of "a plausible model" of allosteric proteins to the receptor for acetylcholine. J Theor Biol 16:306-320.

Krasowski MD, Nishikawa K, Nikolaeva N, Lin A, and Harrison NL (2001) Methionine 286 in transmembrane domain 3 of the $\mathrm{GABA}_{\mathrm{A}}$ receptor $\beta$ subunit controls a binding cavity for propofol and other alkylphenol general anesthetics. Neuropharmacology 41:952-964.

Loewe S (1953) The problem of synergism and antagonism of combined drugs. Arzneimittelforschung 3:285-290.

Monod J, Wyman J, and Changeux JP (1965) On the nature of allosteric transitions: a plausible model. J Mol Biol 12:88-118.

Neelands TR, Fisher JL, Bianchi M, and Macdonald RL (1999) Spontaneous and $\gamma$-aminobutyric acid $(\mathrm{GABA})$-activated $\left.\operatorname{GABA}_{\mathrm{A}}\right)$ receptor channels formed by $\varepsilon$ subunit-containing isoforms. Mol Pharmacol 55:168-178.

Nourmahnad A, Stern AT, Hotta M, Stewart DS, Ziemba AM, Szabo A, and Forman SA (2016) Tryptophan and cysteine mutations in M1 helices of $\alpha 1 \beta 3 \gamma 2 \mathrm{~L}$ $\gamma$-aminobutyric acid type A receptors indicate distinct intersubunit sites for four intravenous anesthetics and one orphan site. Anesthesiology 125:1144-1158.

Richardson JE, Garcia PS, O'Toole KK, Derry JM, Bell SV, and Jenkins A (2007) A conserved tyrosine in the $\beta 2$ subunit M4 segment is a determinant of $\gamma$-aminobutyric acid type A receptor sensitivity to propofol. Anesthesiology 107: $412-418$.

Ruesch D, Neumann E, Wulf H, and Forman SA (2012) An allosteric coagonist model for propofol effects on $\alpha 1 \beta 2 \gamma 2 \mathrm{~L} \gamma$-aminobutyric acid type A receptors. Anesthesiology 116:47-55.

Shin DJ, Germann AL, Johnson AD, Forman SA, Steinbach JH, and Akk G (2018) Propofol is an allosteric agonist with multiple binding sites on concatemeric ternary $\mathrm{GABA}_{\mathrm{A}}$ receptors. Mol Pharmacol 93:178-189.

Shin DJ, Germann AL, Steinbach JH, and Akk G (2017) The actions of drug combinations on the $\mathrm{GABA}_{\mathrm{A}}$ receptor manifest as curvilinear isoboles of additivity. Mol Pharmacol 92:556-563.

Steinbach JH and Akk G (2001) Modulation of $\operatorname{GABA}\left({ }_{\mathrm{A}}\right)$ receptor channel gating by pentobarbital. J Physiol 537:715-733.

Stewart D, Desai R, Cheng Q, Liu A, and Forman SA (2008) Tryptophan mutations at azi-etomidate photo-incorporation sites on $\alpha 1$ or $\beta 2$ subunits enhance $\mathrm{GABA}_{\mathrm{A}}$ receptor gating and reduce etomidate modulation. Mol Pharmacol 74:1687-1695.

Tallarida RJ (2006) An overview of drug combination analysis with isobolograms. $J$ Pharmacol Exp Ther 319:1-7.

Thompson SA, Bonnert TP, Cagetti E, Whiting PJ, and Wafford KA (2002) Overexpression of the $\left.\operatorname{GABA}_{\mathrm{A}}\right)$ receptor $\varepsilon$ subunit results in insensitivity to anaesthetics. Neuropharmacology 43:662-668.

Thompson SA, Smith MZ, Wingrove PB, Whiting PJ, and Wafford KA (1999) Mutation at the putative $\left.\mathrm{GABA}_{\mathrm{A}}\right)$ ion-channel gate reveals changes in allosteric modulation. Br J Pharmacol 127:1349-1358.

Yip GM, Chen ZW, Edge CJ, Smith EH, Dickinson R, Hohenester E, Townsend RR, Fuchs K, Sieghart W, Evers AS, et al. (2013) A propofol binding site on mammalian $\mathrm{GABA}_{\mathrm{A}}$ receptors identified by photolabeling. Nat Chem Biol 9:715-720.

Ziemba AM and Forman SA (2016) Correction for inhibition leads to an allosteric co-agonist model for pentobarbital modulation and activation of $\alpha 1 \beta 3 \gamma 2 \mathrm{~L} \mathrm{GABA}_{\mathrm{A}}$ receptors. PLoS One 11:e0154031.

Address correspondence to: Gustav Akk, Department of Anesthesiology, Washington University School of Medicine, Campus Box 8054, 660 South Euclid Ave., St. Louis, MO 63110. E-mail: akk@morpheus.wustl.edu 